\title{
The prognostic significance of human epidermal growth factor receptor family protein expression in operable pancreatic cancer
}

\section{HER1-4 protein expression and prognosis in pancreatic cancer}

Qin $\mathrm{Li}^{1}$, Lei Zhang ${ }^{2}$, XiuHong $\mathrm{Li}^{3}$, Han Yan ${ }^{1}$, Liuting Yang ${ }^{4}$, Yingying $\mathrm{Li}^{5}$, Teng $\mathrm{Li}^{1}$, Jing Wang ${ }^{1}$ and Bangwei Cao ${ }^{1,6^{*}}$

\begin{abstract}
Background: Prognostic factors aid in the stratification and treatment of cancer. This study evaluated the prognostic significance of human epidermal growth factor receptor (HER) family members (HER1-4) expression in patients with operable pancreatic cancer.

Methods: The expression of individual HER proteins in patient tissue specimens was detected by immunohistochemistry staining. Patient follow-up time was between 1.0 and 78.1 months.

Results: Positive expression of HER1, HER2, HER3 and HER4 was detected in 41.4, 60.0, 24.3 and 65.7\% of cases, respectively. Kaplan-Meier analysis revealed that HER3 positive expression was associated with decreased median survival time (12.0 vs. 25.6 months for HER3 positive and negative groups, respectively; $P=0.013$ ). Cox's regression confirmed that positive HER3 expression was an independent predictor of poor survival ( $R R=3.684, P=0.001)$. In contrast, HER4 negative patients had a significantly decreased median survival time when compared with HER4 positive patients (11.4 vs. 25. 6 months, respectively; $P=0.027$ ). However, HER4 was not an independent predictor of survival. No significant association between HER1 or HER2 expression and survival was observed $(P=0.626 \& P=0.859$, respectively).

Conclusions: HER3 is an independent prognostic marker for patients with operable pancreatic cancer. HER4 may also be of potential prognostic value in this disease and deserves further attention.
\end{abstract}

Keywords: Pancreatic cancer, Prognosis, HER1, HER2, HER3

\section{Background}

Pancreatic cancer is the fourth leading cause of cancerrelated death in the United States with a 5-year survival rate of only $5 \%$ [1]. The majority of patients are diagnosed in the late stages of disease both because of a lack of effective early detection methods and a lack of recognizable symptoms. Although surgical resection offers the best hope for long-term survival [2], post-surgery relapse or

\footnotetext{
*Correspondence: oncology@ccmu.edu.cn

'Department of Oncology, Beijing Friendship Hospital, Capital Medical University, Beijing 100050, China

${ }^{6}$ Beijing Key Laboratory for Precancerous Lesion of Digestive Diseases, Beijing

Friendship Hospital, Capital Medical University, Beijing, China

Full list of author information is available at the end of the article
}

metastasis are inevitable [3]. As a result, there is an urgent need to discover new biomarkers to aid in predicting prognosis and developing curative strategies against pancreatic cancer.

The human epidermal growth factor receptor (HER) family belongs to the tyrosine kinase receptor superfamily. It includes four highly homologous members, HER1, HER2, HER3 and HER4. HER family proteins and their associated downstream signaling networks regulate cellular activities such as gene expression, mitosis, differentiation, proliferation, survival, migration, invasion, and apoptosis $[4,5]$. In the clinic, targeted therapy directed at HER family proteins is well established. The small molecule HER1 tyrosine kinase inhibitor gefitinib has been used in the 
fist-line treatment of advanced non-small cell lung cancer associated with HER1 mutation [6]. The anti-HER1 monoclonal antibody cetuximab has been used in the targeted therapy of head and neck squamous cell carcinoma, colorectal cancer and advanced non-small cell lung cancer [7-9]. The anti-HER2 monoclonal antibody trastuzumab has been used in the targeted therapy of HER2-positive advanced breast and gastric cancers $[10,11]$. The bispecific antibody MM-111 and anti-HER3 antibody patritumab both inhibit the activation of HER3 and demonstrate antitumor activity $[12,13]$, while HER4 represents a potential molecular target for melanoma [14]. HER family proteins are also of important clinical significance in determining prognosis in a variety of solid tumors. HER1 overexpression is associated with increased depth of invasion, vascular invasion, and poor prognosis in esophagus squamous cell carcinoma [15]. HER2 overexpression is associated with shorter time to progression and decreased survival in breast cancer [16]. HER2 and HER3 are both predictors of poor outcome in gastric cancer $[17,18]$. Data on the prognostic value of HER4 in solid tumors are less clear. However, a study by Barnes et al. demonstrated that absence of HER4 expression could predict the recurrence of ductal carcinoma in situ of the breast [19].

The prognostic significance of HER family protein expression in operable pancreatic cancer remains unclear. This study was to investigate the expression status of HER family proteins (HER1-4) in tissue specimens obtained from patients with operable pancreatic cancer. A detailed analysis of the relationship between HER family expression status and patient survival was performed, and factors that represented independent predictors of prognosis were identified.

\section{Methods}

\section{Cell culture, antibodies and other reagents}

The AsPC-1 human pancreatic cancer cell line was obtained from the experimental center of Beijing Friendship Hospital. Cells were cultured in Dulbecco's Modified Eagle Medium supplemented with $10 \%$ fetal bovine serum and maintained at $37{ }^{\circ} \mathrm{C}$ in a humidified incubator containing 5\% CO2.

For western blotting, rabbit monoclonal antibodies against phospho-HER3 (Y1289) and beta-actin were purchased from Cell Signaling Technology. The anti-HER3 monoclonal therapeutic antibody (clone 3D4) was obtained from Beijing Cotimes Biotech Co., Ltd. and used at $2.5 \mu \mathrm{l} / \mathrm{ml}$ for $0.5 \mathrm{~h}$. The anti-human HER2 antibody (Herceptin) was purchased from Shanghai Roche Pharmaceuticals co., LTD and was used at $7 \mathrm{ul} / \mathrm{ml}$ for $2.5 \mathrm{~h}$.

\section{3-(4,5-dimethylthiazol-2-yl)-2,5-diphenyltetrazolium bromide (MTT) assay}

To perform MTT-based cell proliferation assays, cells in the logarithmic phase of growth were seeded in triplicate in 96-well plates at a density of $0.5 \times 104$ cells/well. Cells were then treated with serially diluted anti-HER3 monoclonal antibody (clone 3D4, Beijing Cotimes Biotech Co., Ltd.) for $48 \mathrm{~h}$, after which $10 \mu \mathrm{l}$ of a $5 \mathrm{mg} / \mathrm{ml}$ stock of MTT (Sigma) was added to the wells. The cells were incubated at $37^{\circ} \mathrm{C}$ for an additional $4 \mathrm{~h}$, and the reaction then stopped by treating the cells with $150 \mu \mathrm{l}$ of DMSO for $5 \mathrm{~min}$. The optical density was then measured at $490 \mathrm{~nm}$. A control group that received no antibody treatment was used as a reference for calculating relative cell survival.

\section{Western blotting analysis}

AsPC-1 human pancreatic cancer cell line were lysed, and cell lysates were resolved on 7.5\% SDS-PAGE gels, and the proteins then electrophoretically transferred onto nitrocellulose membranes. Blotting membranes were blocked for $1 \mathrm{~h}$ and incubated with primary antibody overnight at $4{ }^{\circ} \mathrm{C}$. Goat anti- $\beta$-actin was used as a loading control. Membranes were washed with Trisbuffered saline/0.5\% Tween 20 and then incubated with anti-rabbit (for primary antibodies against HER family proteins) or goat (for the primary $\beta$-actin antibody) $\lg G$ secondary antibody conjugated to horseradish peroxidase. For protein visualization, nitrocellulose membranes were incubated for 2-3 mins with Western HRP Substrate and the chemiluminescent product then detected following exposure to KODAK film.

\section{Patients}

Seventy patients who underwent surgical resection for primary pancreatic cancer at the Beijing Friendship Hospital between January 2008 and December 2012 were enrolled in this study. Complete clinical, pathological and followup data were obtained for all patients. Clinical data including age, sex, family tumor history, smoking and drinking history, and CA 19-9 score were recorded. Pathological data including tumor location, margins, histology grade, histopathology type, primary tumor $(\mathrm{T})$, lymph nodes $(\mathrm{N})$ and the number of positive lymph nodes were also collected. The median age of all patients was 62 years, with a range of $18-80$ years. Follow-up time was between 1.0 and 78.1 months. The deadline of follow-up was December 31, 2015, or the data of patient death.

\section{Immunohistochemistry (IHC) and tissue scoring}

Five-micron-thick sections were prepared from formalinfixed, paraffin-embedded tissues derived from surgically resected pancreatic cancer specimens. Immunohistochemical samples were individually assessed without knowledge of patient outcome. Prior to staining, each slide was deparaffinized and heated in citrate buffer. After cooling and rinsing in Tris buffer, immunohistochemical staining was performed using an automated IHC autostainer. 
The kits for the detection of HER family proteins (HER1-4) were purchased from Santa Cruz Biotechnology. Inc. Anti-HER1 antibody (sc-03, Rabbit polyclonal IgG), anti-HER2 antibody (sc-284, Rabbit polyclonal IgG), antiHER3 antibody (sc-285, Rabbit polyclonal IgG), and antiHER4 antibody (sc-283, Rabbit polyclonal IgG) were used at a dilution of 1:200, 1:200, 1:20, and 1:40, respectively. Detection of HER family proteins was performed using a secondary mouse anti-immunoglobulin antibody linked to biotin in conjunction with streptavidin linked to horseradish peroxidase.

Slides were scored independently by two individuals using a 4-point intensity scale system, and any discrepancies in scores were resolved by an arbiter. HER protein staining was scored as either $0,1+, 2+$, or $3+$, the cytoplasm and membrane-staining intensity and pattern were evaluated according to the following scale [20]: no staining is observed or is observed in less than $10 \%$ of the tumor cells (score 0 ), weak staining is detected in $10 \%$ or more tumor cells (score $1+$ ), moderate staining is observed in $10 \%$ or more tumor cells (score $2+$ ) and strong staining is observed in $10 \%$ or more tumor cells (score 3). Scores of $0,1+$ and $2+$ were taken to represent negative protein expression, while a score of was 3+ was taken to represent positive protein expression.

\section{Statistical analysis}

Survival time was calculated in months from the date of surgery to the date of death, or date of final contact as of December 31, 2015. The survival times of patients between different subgroups were compared using the logrank test. The Chi-square test was used to test associations between the expression of HER proteins and clinicopathological parameters. The Kaplan-Meier method was used for survival analysis and the log-rank test to determine the statistical significance of differences between survival curves. Relative risks associated with HER positive expression were calculated by Cox's Multiple Regression analysis. A P value of less than 0.05 was considered significant. Statistical analysis was performed using SPSS 11.0 software (SPSS Inc., Chicago, IL, USA).

\section{Results}

HER3 expression in pancreatic cancer cells and the inhibitory effects of anti-HER3 antibody

Given the significant association observed between HER3 expression and poor survival in patients with many solid tumors, we wished to determine whether this receptor was expressed in pancreatic cancer cells in vitro and, if so, to determine its role in cellular proliferation. High levels of pHER3 expression were confirmed in the AsPC-1 pancreatic cancer cell line by western blotting, anti-HER3 monoclonal antibody (3D4) and anti-HER2 monoclonal antibody (trastuzumab) significantly down-regulated the expression of pHER3, and two drug combination showed synergistic inhibitory effect (Fig. 1a). Furthermore, the treatment of AsPC-1 cells with increasing concentrations of anti-HER3 monoclonal antibody (3D4) resulted in significant inhibition of cellular proliferation at concentrations equal to $20 \mathrm{ug} / \mathrm{ml}$ or $50 \mu \mathrm{g} / \mathrm{ml}(P<0.05)$, as determined by an MTT assay (Fig. 1b).

\section{Expression of HER family proteins in pancreatic tissue specimens}

IHC analysis was performed to determine the expression of HER family proteins in tissue specimens obtained from 70 patients with operable pancreatic cancer. For each receptor, tissue specimens were assigned a score according to the cytoplasm and membrane-staining intensity. Analysis of intensity scores revealed that HER1, HER2, HER3 and HER4 exhibited positive staining in 41.4, 60.0, 24.3 and $65.7 \%$ of cases, respectively. Representative images of immunostaining related to HER1, 2, 3 \& 4 expression in pancreatic cancer tissues are shown in Fig. 2.

\section{Analysis of the relationship between patient characteristics and median survival time in operable pancreatic cancer}

The relationship between the clinical/pathological characteristics and median survival time in patients with operable pancreatic cancer are showed in Table 1. Differences in median survival times (MSTs) between subgroups were evaluated using the log-rank test. The
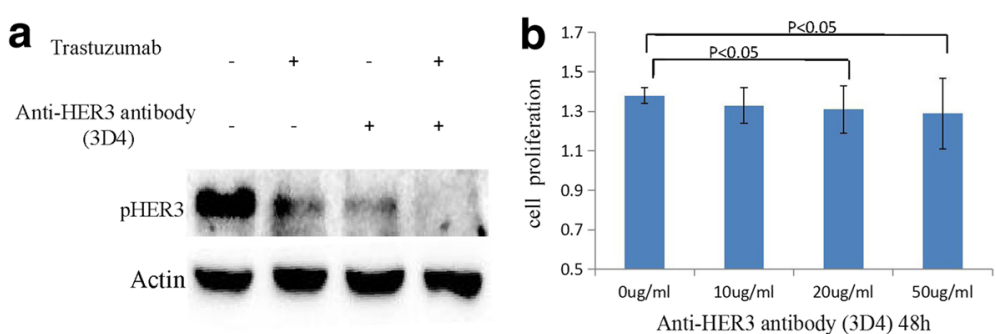

Fig. 1 pHER3 expression in AsPC-1 cells and the inhibitory effect of anti-HER3 monoclonal antibody (3D4). a. pHER3 was overexpressed in the AsPC-1 cells. Both 3D4 and trastuzumab significantly down-regulated the expression of pHER3, and two drug combination showed synergistic inhibitory effect. b. 3D4 significantly inhibited cellular proliferation at concentrations equal to $20 \mathrm{ug} / \mathrm{ml}$ or $50 \mu \mathrm{g} / \mathrm{ml}(P<0.05)$ 


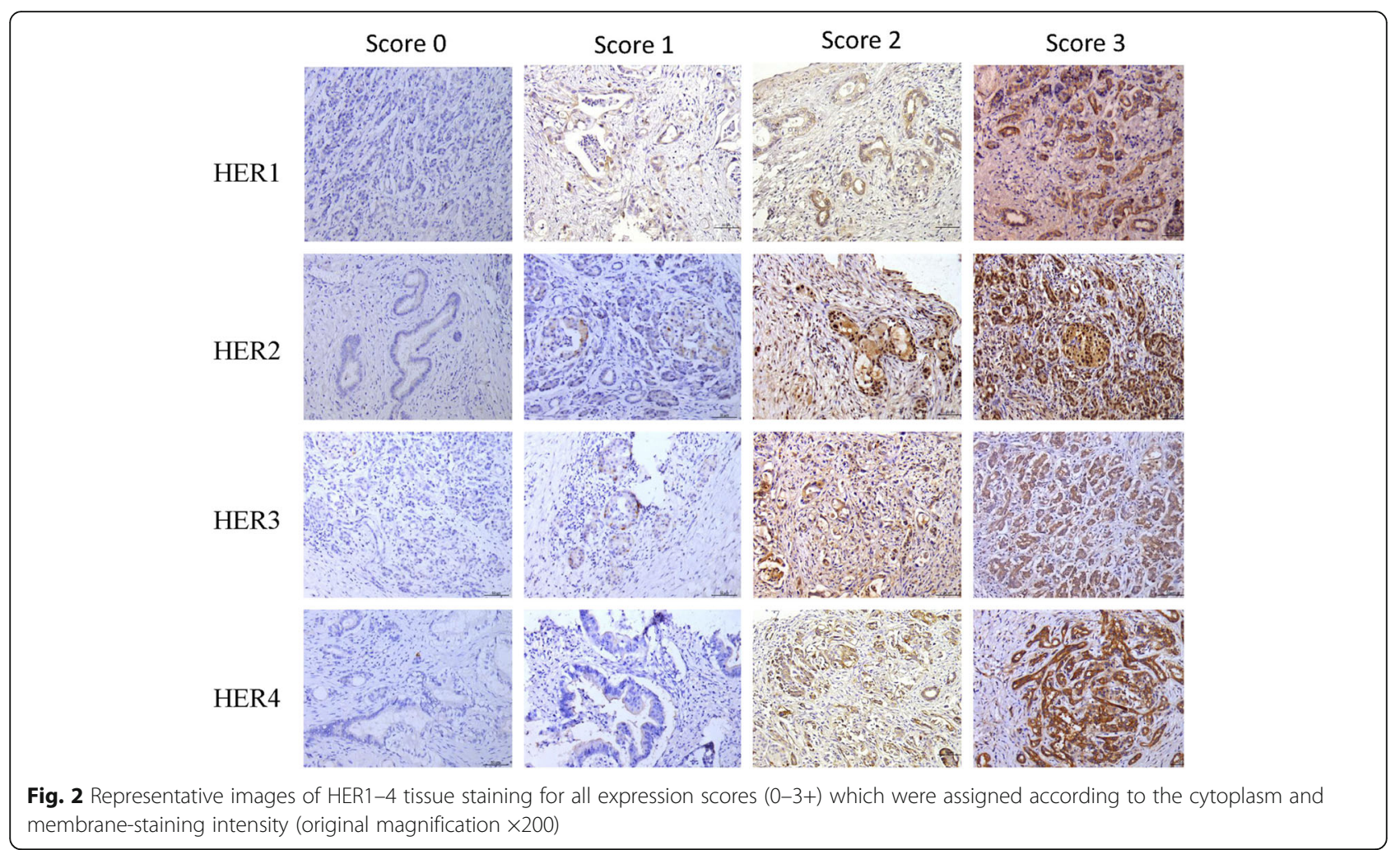

MSTs of patients with stump cancer, low differentiation, adenocarcinoma, N1 stage, and CA 19-9 >1200U/ml were significantly lower than those of patients from the corresponding control subgroups (4.87 vs. 17.69 months, $P<0.001 ; 9.34$ vs. 33.21 months, $P<0.001 ; 13.38$ vs. 49.18 months, $P<0.001$; 11.57 vs. 34.65 months, $P=0.007$; 10.59 vs. 32.88 months, $P<0.001$; respectively). No significant differences in MSTs were observed between subgroups of sex, age, smoking history, drinking history, tumor family history, tumor location, $\mathrm{T}$ stage, and $\mathrm{M}$ stage (Table 1).

\section{HER family protein expression status among the different patient subgroups}

The Chi-square test was used to analyze differences in HER family protein expression status between patient subgroups. Significant differences in HER1 expression status were observed between the sex subgroups $(P=$ $0.027)$ and the differentiation subgroups $(P=0.026)$. A significant difference in HER2 expression status was observed between the CA 19-9 subgroups $(P=0.020)$. Significant differences in HER4 expression status were observed between the smoking history subgroups $(P=$ $0.026)$, the drinking history subgroups $(P=0.042)$, the pathology types subgroups $(P=0.014)$ and the T stage subgroups $(P=0.017)$. However, significant differences in HER3 expression status were not observed between any subgroups $(P>0.05$ in all cases; Table 2$)$

\section{Association between HER family protein expression status} and patient survival

IHC analysis of patient tissue specimens revealed that positive HER1, HER2, HER3 and HER4 expression was observed in 41.4, 60.0, 24.3 and $65.7 \%$ of cases, respectively. Differences in patient survival times between the negative and positive expression subgroups for all HER family proteins were analyzed by the Kaplan-Meier method. The analysis showed that the MST for the HER3 positive group was 12.0 months, which was significantly lower than 25.6 months observed for the HER3 negative group $(P=0.013)$. MST for the HER4 positive group was 25.6 months, which was significantly higher than 11.4 months observed for the HER4 negative group $(P=0.027)$. No significant association between HER1 or HER2 expression status and survival time was observed in our analysis $(P=0.626 \& P=0.859$, respectively; Fig. 3 and Table 3 )

\section{Evaluation of HER family protein expression status and clinicopathological characteristics as independent predictors of survival in operable pancreatic cancer}

A large number of factors affected the survival time of patients with operable pancreatic cancer, and Cox's multiple regression analysis was performed to identify those factors that were independent predictors of prognosis. HER family protein expression status along with those clinicopathological parameters which demonstrated significance 
Table 1 The comparison of median survival time in different subgroups

\begin{tabular}{|c|c|c|c|c|}
\hline Variable & Number (\%) & $\begin{array}{l}\text { Median survival } \\
\text { time (months) }\end{array}$ & $\begin{array}{l}\text { Standard error } \\
\text { (months) }\end{array}$ & $P$ value \\
\hline Sex & & & & 0.144 \\
\hline Male & $28(40.0)$ & 11.93 & 3.98 & \\
\hline Female & $42(60.0)$ & 16.64 & 6.11 & \\
\hline Age & & & & 0.059 \\
\hline$<60 y$ & $34(48.6)$ & 49.18 & 16.69 & \\
\hline$\geq 60 y$ & $36(51.4)$ & 13.38 & 2.64 & \\
\hline Tumor family history & & & & 0.795 \\
\hline Yes & $5(7.1)$ & 11.21 & 0.68 & \\
\hline No & 65 (92.9) & 16.64 & 4.38 & \\
\hline Smoking history & & & & 0.591 \\
\hline Yes & 13 (18.6) & 17.23 & 11.98 & \\
\hline No & $57(81.4)$ & 15.88 & 4.18 & \\
\hline Drinking history & & & & 0.902 \\
\hline Yes & $7(10.0)$ & 17.22 & 7.88 & \\
\hline No & $63(90.0)$ & 15.88 & 4.41 & \\
\hline Tumor location & & & & 0.256 \\
\hline Head & $45(64.3)$ & 13.38 & 1.92 & \\
\hline Body + tail & $25(35.7)$ & 17.23 & 5.21 & \\
\hline Stump cancer & & & & 0.000 \\
\hline Yes & $6(8.6)$ & 4.87 & 0.73 & \\
\hline No & $64(91.4)$ & 17.69 & 8.53 & \\
\hline Differentiation & & & & 0.000 \\
\hline Lower & $17(24.3)$ & 9.34 & 2.91 & \\
\hline Higher & $53(75.7)$ & 33.21 & 18.47 & \\
\hline Pathology type & & & & 0.001 \\
\hline Adenocarcinoma & $53(75.7)$ & 13.38 & 1.68 & \\
\hline Non-adenocarcinoma & $17(24.2)$ & 49.18 & 1.02 & \\
\hline T stage & & & & 0.188 \\
\hline $\mathrm{T} 1+\mathrm{T} 2$ & $34(48.6)$ & 22.32 & 11.19 & \\
\hline $\mathrm{T} 3+\mathrm{T} 4$ & $36(51.4)$ & 12.07 & 2.20 & \\
\hline N stage & & & & 0.007 \\
\hline No & $39(55.7)$ & 34.65 & 13.76 & \\
\hline N1 & $31(44.3)$ & 11.57 & 0.79 & \\
\hline M stage & & & & 0.092 \\
\hline MO & 62 (88.6) & 17.23 & 5.86 & \\
\hline M1 & $8(11.4)$ & 7.66 & 4.67 & \\
\hline CA19-9 & & & & 0.000 \\
\hline$<1200 \mathrm{U} / \mathrm{ml}$ & 57 (81.4) & 32.88 & 9.20 & \\
\hline$>1200 \mathrm{U} / \mathrm{ml}$ & 13 (18.6) & 10.59 & 3.29 & \\
\hline
\end{tabular}

following univariate analysis were included in the Cox's multiple regression analysis. Risk of death for the HER3 positive group was 3.684 times greater than that for the HER3 negative group $(P=0.001)$. Differentiation (RR
3.804, $P=0.006$ ), histopathology type (RR 4.595, $P=$ 0.013 ) and stump cancer (RR 10.110, $P=0.001$ ) were also independent predictors of survival. However, the expression status of HER1, HER2 and HER4, positive lymph 
Table 2 The expression of HER1 - HER4 in different subgroups

\begin{tabular}{|c|c|c|c|c|c|c|c|c|c|c|c|c|}
\hline & HER & & & HEF & & & HER & & & HER & & \\
\hline & - & + & $P$ & - & + & $P$ & - & + & $P$ & - & + & $P$ \\
\hline & $n$ & $n$ & & $n$ & $n$ & & $n$ & & & $n$ & $n$ & \\
\hline Sex & & & 0.027 & & & 0.258 & & & 0.564 & & & 0.164 \\
\hline Male & 12 & 16 & & 13 & 15 & & 21 & 7 & & 12 & 16 & \\
\hline Female & 29 & 13 & & 15 & 27 & & 32 & 10 & & 12 & 30 & \\
\hline Age & & & 0.663 & & & 0.519 & & & 0.446 & & & 0.139 \\
\hline$<60 y$ & 19 & 15 & & 14 & 20 & & 25 & 9 & & 9 & 25 & \\
\hline$\geq 60 y$ & 22 & 14 & & 14 & 22 & & 28 & 8 & & 15 & 21 & \\
\hline Tumor family history & & & 0.338 & & & 0.671 & & & 0.237 & & & 0.563 \\
\hline Yes & 2 & 3 & & 2 & 3 & & 5 & 0 & & 2 & 3 & \\
\hline No & 39 & 26 & & 26 & 39 & & 48 & 17 & & 22 & 43 & \\
\hline Smoking history & & & 0.094 & & & 0.579 & & & 0.389 & & & 0.026 \\
\hline Yes & 5 & 8 & & 5 & 8 & & 9 & 4 & & 8 & 5 & \\
\hline No & 36 & 21 & & 23 & 34 & & 44 & 13 & & 16 & 41 & \\
\hline Drinking history & & & 0.310 & & & 0.085 & & & 0.220 & & & 0.042 \\
\hline Yes & 13 & 4 & & 5 & 2 & & 4 & 3 & & 5 & 2 & \\
\hline No & 28 & 25 & & 23 & 40 & & 49 & 14 & & 19 & 44 & \\
\hline Tumor location & & & 0.856 & & & 0.127 & & & 0.589 & & & 0.409 \\
\hline Head & 26 & 19 & & 15 & 30 & & 35 & 10 & & 17 & 28 & \\
\hline Body + tail & 15 & 10 & & 13 & 12 & & 18 & 7 & & 7 & 18 & \\
\hline Pathology types & & & 0.138 & & & 0.233 & & & 0.113 & & & 0.014 \\
\hline Adenocarcinoma & 28 & 24 & & 19 & 33 & & 37 & 15 & & 22 & 30 & \\
\hline Non-adenocarcinoma & 13 & 5 & & 9 & 9 & & 16 & 2 & & 2 & 16 & \\
\hline Differentiation & & & 0.026 & & & 0.167 & & & 0.144 & & & 0.570 \\
\hline Lower & 6 & 11 & & 9 & 8 & & 15 & 2 & & 6 & 11 & \\
\hline Higher & 35 & 18 & & 19 & 34 & & 38 & 15 & & 18 & 35 & \\
\hline T stage & & & 0.663 & & & 0.330 & & & 0.164 & & & 0.017 \\
\hline $\mathrm{T} 1+\mathrm{T} 2$ & 19 & 15 & & 15 & 19 & & 28 & 6 & & 7 & 27 & \\
\hline $\mathrm{T} 3+\mathrm{T} 4$ & 22 & 14 & & 13 & 23 & & 25 & 11 & & 17 & 19 & \\
\hline N stage & & & 0.566 & & & 0.480 & & & 0.496 & & & 0.329 \\
\hline No & 23 & 16 & & 15 & 24 & & 29 & 10 & & 12 & 27 & \\
\hline N1 & 18 & 13 & & 13 & 18 & & 24 & 7 & & 12 & 19 & \\
\hline M stage & & & 0.273 & & & 0.598 & & & 0.091 & & & 0.269 \\
\hline MO & 35 & 27 & & 25 & 37 & & 49 & 13 & & 20 & 42 & \\
\hline M1 & 6 & 2 & & 3 & 5 & & 4 & 4 & & 4 & 4 & \\
\hline CA199 & & & 0.467 & & & 0.020 & & & 0.332 & & & 0.480 \\
\hline$<1200 \mathrm{U} / \mathrm{ml}$ & 34 & 23 & & 19 & 38 & & 42 & 15 & & 19 & 38 & \\
\hline$>1200 \mathrm{U} / \mathrm{ml}$ & 7 & 6 & & 9 & 4 & & 11 & 2 & & 5 & 8 & \\
\hline
\end{tabular}

node number, N stage and CA 19-9 score could not independently predict survival $(P>0.05$ in all cases; Table 4$)$.

\section{Discussion}

There are relatively few studies on the prognostic significance of HER family members in patients with operable pancreatic cancer. To date, the findings regarding the prognostic significance of HER family protein expression in pancreatic cancer have been inconsistent. This may be a consequence of inter-study differences in tissue preparation, the detection antibodies used, and different methods of scoring. In our study we performed a comprehensive analysis of the prognostic value of HER1-4 in patients with operable pancreatic cancer. 

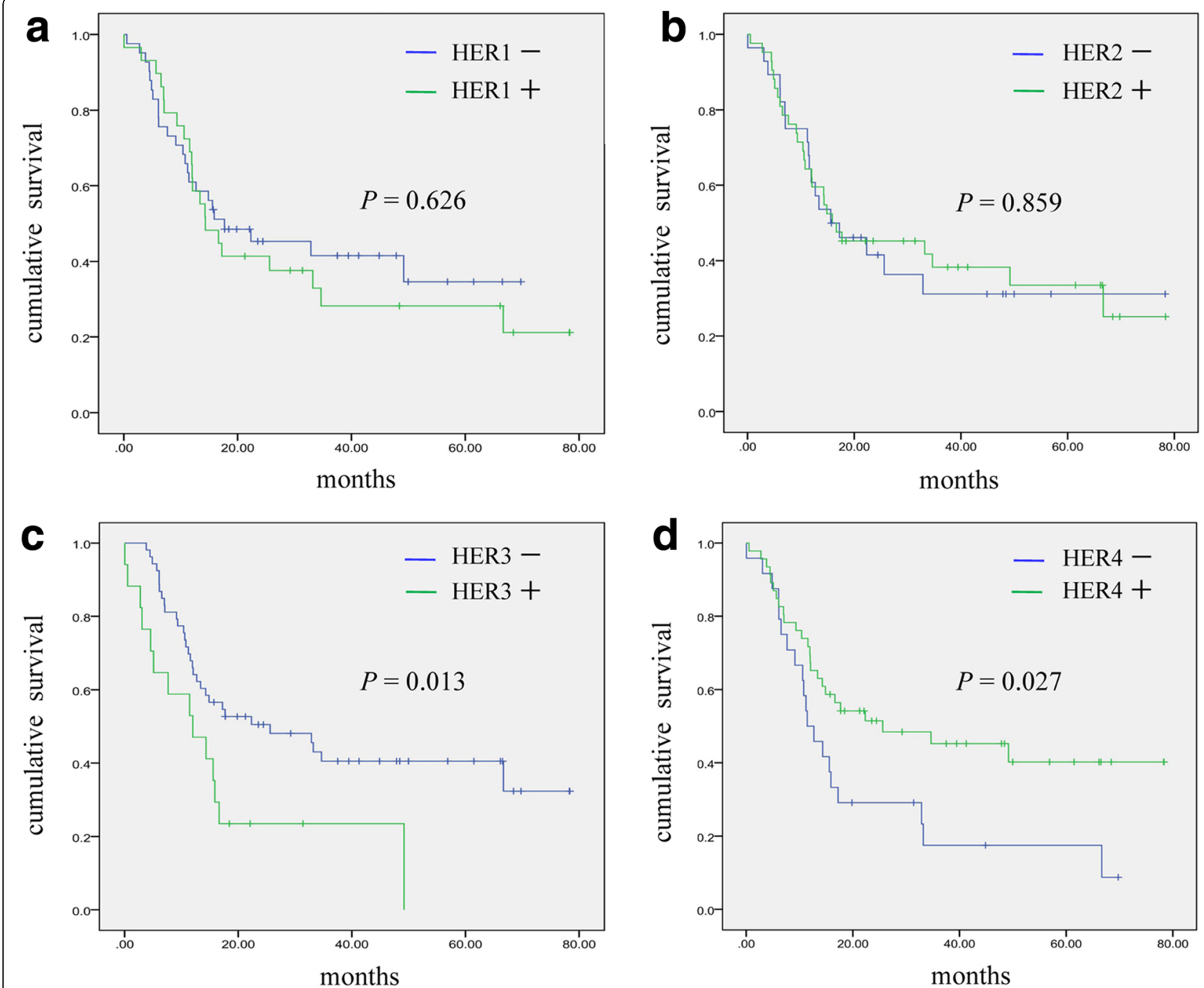

Fig. 3 Kaplan-Meier survival curve analysis. Patients were categorized according to HER positive and negative expression status. Curves show overall survival differences according to HER1 (a), HER2 (b), HER3 (c), and HER4 (d) expression status

Table 3 The cancer-specific survival and HER1 - HER4 expression

\begin{tabular}{|c|c|c|c|c|}
\hline Variable & Number (\%) & Mean value (months) & Median survival time (months) & $P$ value (for median survival time) \\
\hline HER1 & & & & 0.626 \\
\hline Negative & $41(58.6)$ & 34.0 & 17.7 & \\
\hline Positive & $29(41.4)$ & 31.4 & 14.3 & \\
\hline HER2 & & & & 0.859 \\
\hline Negative & $28(40.0)$ & 33.4 & 15.6 & \\
\hline Positive & $42(60.0)$ & 35.1 & 15.9 & \\
\hline HER3 & & & & 0.013 \\
\hline Negative & $53(75.7)$ & 39.1 & 25.6 & \\
\hline Positive & $17(24.3)$ & 18.1 & 12.0 & \\
\hline HER4 & & & & 0.027 \\
\hline Negative & $24(34.3)$ & 24.5 & 11.4 & \\
\hline Positive & $46(65.7)$ & 40.6 & 25.6 & \\
\hline
\end{tabular}


Table 4 Cox's multiple regression analysis for survival time

\begin{tabular}{lcll}
\hline Variable & Relative risk & $95 \%$ confidence interval & $P$ value \\
\hline HER1 positive vs. negative & 0.598 & $0.281-1.271$ & 0.181 \\
HER2 positive vs. negative & 0.909 & $0.420-1.968$ & 0.809 \\
HER3 positive vs. negative & 3.684 & $1.732-7.834$ & 0.001 \\
HER4 positive vs. negative & 0.800 & $0.375-1.710$ & 0.565 \\
Stump cancer yes vs. no & 10.110 & $2.725-37.506$ & 0.001 \\
Histopathology type & 4.595 & $1.371-15.404$ & 0.013 \\
$\quad$ Adenocarcinoma vs. non-adenocarcinoma & & $1.480-9.774$ & 0.006 \\
Differentiation poor vs. well & 3.804 & $0.259-1.685$ & 0.386 \\
N stage N1 vs. No & 0.661 & $0.964-1.838$ & 0.083 \\
The positive lymph node number & 1.331 & $0.806-4.770$ & 0.138 \\
CA199 $>1200 \mathrm{U} / \mathrm{ml}$ vs. $<1200 \mathrm{U} / \mathrm{ml}$ & 1.961 &
\end{tabular}

Kaplan-Meier analysis showed that the MST of the HER3 positive group was 12.0 months, which was significantly lower than 25.6 months observed for the HER3 negative group $(P=0.013)$. Cox's multiple regression analysis demonstrated that HER3 was an independent predictor of poor prognosis; risk of death associated with HER3 positive expression was 3.684 times greater than that associated with HER3 negative expression $(P=$ 0.001). Although Cox's multiple regression analysis did not identify HER4 positive expression as an independent predictor of survival, Kaplan-Meier analysis did show that the MST of the HER4 positive group was 25.6 months, which was significantly higher than 11.4 months for the HER4 negative group $(P=0.027)$. This suggests that HER4 may be of some potential prognostic value in pancreatic cancer and this deserves further attention. No significant association between HER1 or HER2 positive expression and survival were observed, and neither receptor was a predictor of survival.

HER1 is overexpressed in a variety of human malignancies $[21,22]$. The frequency of HER1 expression in pancreatic cancer has been reported as 30.4\% [23] and 45.1\% [25] in two previous studies. In our study HER1 expression was observed in $41.4 \%$ of patients. HER 1 overexpression has previously been associated with decreased survival [23, 24], and the cumulative 1-, 3- and 5 -year survival rates were 48, 20 and 18\%, respectively [24]. A previous meta-analysis has shown that three trials reported a survival disadvantage for patients with HER1 expression, while other five trials reported no significant difference, however, the combined hazard ratio was $1.225(P=0.035)$ [25]. Another meta-analysis drew the opposite conclusion that HER1 was not a significant prognostic factor in resected pancreatic cancer $(\mathrm{HR}=$ 1.35, 95\% CI 0.80-2.27, P> 0.05) [26]. From our analysis, we also drew the conclusion that positive HER1 expression has no prognostic value in operable pancreatic cancer.
HER2 expression is associated with decreased diseasespecific survival and poor prognosis in patients with breast cancer and gastric cancer $[17,18,27]$. The frequency of HER2 expression and its association with survival in pancreatic cancer remains unclear. Te Velde et al. reported that neither membranous overexpression nor gene amplification of HER2 was seen in pancreatic cancer [28]. A study by Aumayr, et al. observed positive HER2 expression, as determined by IHC staining, in $10 \%$ of pancreatic cancer cases, and of these, 7\% demonstrated HER2 gene amplification [29]. In our study we observed positive HER2 expression in $60.0 \%$ of cases, which is significantly higher than that observed by others. Komoto et al. reported that patients with HER2 overexpression had significantly shorter survival times than those with normal HER2 expression (14.7 vs. 20.7 months, $P=0.008$ ), and multivariate survival analysis demonstrated that HER2 was an independent prognostic factor (HR 1.806; $P=$ 0.026) [30]. In our study, however, no significant association between HER2 expression and survival time was observed, and there was no prognostic value associated with positive HER2 expression.

Our study has confirmed the high expression of pHER3 in the AsPC-1 pancreatic cancer cell line by western blotting, and anti-HER3 monoclonal antibody could significantly down-regulated pHER3 level. Furthermore, the treatment of AsPC-1 cells with increasing concentrations of anti-HER3 monoclonal antibody resulted in significant inhibition of cellular proliferation. HER2/HER3 heterodimers are reported to be activated in pancreatic cancer [31], the fact that anti-HER3 monoclonal antibody (3D4) and anti-HER2 monoclonal antibody (trastuzumab) synergetic down-regulated pHER3 in the AsPC-1 cell indirectly proved the simultaneous inactivation of HER2/HER3 heterodimers. These results of Thomas $\mathrm{G}$ et al. and our study are identical. However, the diverse coexistence of HER family homo or heterodimers (HER2/HER2, HER1/ HER2, HER1/HER3 and HER2/HER3) and differences in 
detection methods may explain the non-parallel expression of HER2 and HER3. Studies on the predictive value of HER3 expression on patient outcome in solid tumors are limited. A meta-analysis has reported HER3 overexpression in $42.2 \%$ of solid tumors [32] and an association between HER3 expression and worse overall survival at both 3 years $(\mathrm{OR}=2.24, P<0.001)$ and 5 years $(\mathrm{OR}=2.20$, $P<0.001)$ [32]. Thomas et al. reported that HER3 was expressed in $27 \%$ of the 45 cases of pancreatic ductal adenocarcinoma, which was similar to the $24.3 \%$ reported in our study [31]. The study by Thomas et al. showed that HER3 expression was essential for pertuzumab efficacy in HER2low pancreatic cancer, and that HER3 expression may be a predictive biomarker for pertuzumab efficacy [31]. Hirakawa at al. reported that the MST for patients with curatively resected pancreatic cancer associated with HER3 overexpression was 37.2 months, while that for HER3-negative patients was 58.6 months $(P=0.008)$ [20], the findings was similar to those of our study; our Cox's regression analysis demonstrated that the risk of death associated with HER3 positive expression was 3.684 fold greater than that associated with HER3 negative expression. We therefore conclude that HER3 is a novel independent prognostic biomarker for poor survival in patients with pancreatic cancer.

Clinical research reports on the significance of HER4 expression in the prognosis of patients with solid tumors are less numerous than for other HER family members. It has been reported that the level of HER4 in pancreatic cancer specimens, as determined by IHC, has no association with patient survival [33]. A study by ThybuschBernhardt et al. suggested that HER1 and HER2 overexpression contributes to a more aggressive phenotype and that lack of HER4 expression may increase the metastatic capacity of pancreatic cancer cells [34]. This is consistent with our finding that the MST for the HER4 positive patient group was significantly higher than that for the HER4 negative group (25.6 vs. 11.4 months, $P=$ 0.027). Moreover, HER4 expression was negatively associated with adenocarcinoma, which was shown to be a poor outcome indicator in our study. However, Cox's regression analysis did not identify HER4 as an independent predictor of survival.

\section{Conclusions}

In conclusion, our study shows that HER3 is a novel independent prognostic marker for patients with operable pancreatic cancer. There is a potentially positive advantage associated with HER4 expression which deserves further attention. The prognostic significance associated with HER1 and HER2 expression in operable pancreatic cancer was not found. By analyzing the expression of all HER family members together within a single study enable us to ensure consistency in specimen processing, detection, and scoring methods. This approach enables more robust conclusions to be drawn when comparing the prognostic significance of the single HER family proteins. However, our study is limited by the small number of cases, and a larger cohort prospective study is necessary to confirm our conclusions. The interactions among ligands, HER family members and downstream signaling molecules are intricate, and the patterns of coexpression of the signaling molecules will need to be taken into account to fully understand the prognostic significance within a given disease context. Advances in detection technology and standardization of diagnosis criteria will continue to improve methods for determining the prognostic value of HER family members in operable pancreatic cancer.

\section{Abbreviations \\ HER: Human epidermal growth factor receptor; IHC: Immunohistochemistry; MST: Median survival times}

\section{Acknowledgements}

We wish to thank for Dr. Wei Guo for the discussion and guidance of operation related content.

\section{Funding}

This work was supported by the National Natural Science Foundation of China (Grant No. 81301912 and 81272615), the Beijing Municipal Health System High-level Health Person Foundation Project (Grant No. 2014-3-005), the Beijing Municipal Science and Technology Commission (Capital Features, 2016-2018, awarded to Qin Li), and the Capital Health Research and Development Project (2016-2018, awarded to Jing Wang).

\section{Availability of data and materials}

The datasets supporting the conclusions of this article are included within the article and its additional files.

\section{Authors' contributions}

QL and BWC designed the study; QL and HY developed the methodology and performed the analysis; XHL, LZ, YYL, JW and TL collected data; QL and LTY analyzed data; and QL wrote the first draft. All authors contributed to the review and revision of the manuscript, and All authors read and approved the final manuscript.

\section{Competing interests}

The authors declare that they have no competing interests.

Consent for publication

Not applicable.

\section{Ethics approval and consent to participate}

This study was approved by the Ethics Committee of the Beijing Friendship Hospital and written informed consent was obtained from all participants.

\section{Author details \\ 'Department of Oncology, Beijing Friendship Hospital, Capital Medical University, Beijing 100050, China. ${ }^{2}$ Department of Pathology, Beijing Friendship Hospital, Capital Medical University, Beijing, China. ${ }^{3}$ Research Experiments Center, Beijing Friendship Hospital, Capital Medical University, Beijing, China. ${ }^{4}$ Department of Biochemistry and Molecular Biology, Basic Medical College, Shanxi Medical University, Taiyuan, China. ${ }^{5}$ Department of Pathology and Pathophysiology, Basic Medical College, Capital Medical University, Beijing, China. ${ }^{6}$ Beijing Key Laboratory for Precancerous Lesion of Digestive Diseases, Beijing Friendship Hospital, Capital Medical University, Beijing, China.}

Received: 4 June 2016 Accepted: 25 October 2016 Published online: 21 November 2016 


\section{References}

1. Siegel R, Naishadham D, Jemal A. Cancer statistics, 2013. CA Cancer J Clin. 2013;63:11-30

2. Sohn TA, Yeo CJ, Cameron $J$, Koniaris L, Kaushal S, Abrams RA, et al. Resected adenocarcinoma of the pancreas-616 patients: results, outcomes, and prognostic indicators. J Gastrointest Surg. 2000:4:567-79.

3. Katz MH, Wang H, Fleming JB, Sun CC, Hwang RF, Wolff RA, et al. Long-term survival after multidisciplinary management of resected pancreatic adenocarcinoma. Ann Surg Oncol. 2009;16:836-47.

4. Olayioye MA, Neve RM, Lane HA, Hynes NE. The ErbB signaling network: receptor heterodimerization in development and cancer. EMBO J. 2000;19:3159-67.

5. Yarden Y, Sliwkowski MX. Untangling the ErbB signalling network. Nat Rev Mol Cell Biol. 2001:2:127-37.

6. Gridelli C, De Marinis F, Di Maio M, Cortinovis D, Cappuzzo F, Mok T, et al. Gefitinib as first-line treatment for patients with advanced non-small-cell lung cancer with activating epidermal growth factor receptor mutation: review of the evidence. Lung Cancer. 2011;71:249-57.

7. Tejani MA, Cohen RB, Mehra R. The contribution of cetuximab in the treatment of recurrent and/or metastatic head and neck cancer. Biologics. 2010:4:173-85.

8. Lievre A, Bachet JB, Boige V, Cayre A, Corre DL, Buc E, et al. KRAS mutations as an independent prognostic factor in patients with advanced colorectal cancer treated with cetuximab. J Clin Oncol. 2008;26:374-9.

9. Pirker R, Pereira JR, Szczesna A, von Pawel J, Krzakowski M, Ramlau R, et al. Cetuximab plus chemotherapy in patients with advanced non-small-cell lung cancer (FLEX): an open-label randomised phase III trial. Lancet. 2009:373:1525-31.

10. Slamon DJ, Leyland-Jones B, Shak S, Paton V, Bajamonde A, Fleming T, et al. Use of chemotherapy plus a monoclonal antibody against HER2 for metastatic breast cancer that overexpresses HER2. N Engl J Med. 2001;344:783-92.

11. Bang YJ, Van Cutsem E, Feyereislova A, Chung HC, Shen L, Sawaki A, et al. Trastuzumab in combination with chemotherapy versus chemotherapy alone for treatment of HER2-positive advanced gastric or gastrooesophageal junction cancer (ToGA): a phase 3, open-label, randomised controlled trial. Lancet. 2010;376:687-97.

12. McDonagh CF, Huhalov A, Harms BD, Adams S, Paragas V, Oyama S, et al. Antitumor activity of a novel bispecific antibody that targets the ErbB2/ ErbB3 oncogenic unit and inhibits heregulin-induced activation of ErbB3. Mol Cancer Ther. 2012;11:582-93.

13. Kawakami H, Okamoto I, Yonesaka K, Okamoto K, Shibata K, Shinkai Y, et al. The anti-HER3 antibody patritumab abrogates cetuximab resistance mediated by heregulin in colorectal cancer cells. Oncotarget. 2014:5:11847-56.

14. Lau C, Killian K, Samuels Y, Rudloff U. ERBB4 mutation analysis: emerging molecular target for melanoma treatment. Methods Mol Biol. 2014;1102:461-80.

15. Wang J, Yu JM, Jing SW, Guo Y, Wu YJ, Li N, et al. Relationship between EGFR over-expression and clinicopathologic characteristics in squamous cell carcinoma of the esophagus: a meta-analysis. Asian Pac J Cancer Prev. 2014;15:5889-93.

16. Abd El-Rehim DM, Pinder SE, Paish CE, Bell JA, Rampaul RS, Blamey RW, et al. Expression and co-expression of the members of the epidermal growth factor receptor (EGFR) family in invasive breast carcinoma. Br J Cancer. 2004; 91:1532-42.

17. Begnami MD, Fukuda E, Fregnani JH, Nonogaki S, Montagnini AL, da Costa WL, et al. Prognostic implications of altered human epidermal growth factor receptors (HERs) in gastric carcinomas: HER2 and HER3 are predictors of poor outcome. J Clin Oncol. 2011;29:3030-6.

18. Wang S, Zheng G, Chen L, Xiong B. Effect of HER-2/neu over-expression on prognosis in gastric cancer: a meta-analysis. Asian Pac J Cancer Prev. 2011; 12:1417-23.

19. Barnes NL, Khavari S, Boland GP, Cramer A, Knox WF, Bundred NJ, et al. Absence of HER4 expression predicts recurrence of ductal carcinoma in situ of the breast. Clin Cancer Res. 2005;11:2163-8.

20. Hirakawa T, Nakata B, Amano R, Kimura K, Shimizu S, Ohira G, et al. HER3 overexpression as an independent indicator of poor prognosis for patients with curatively resected pancreatic cancer. Oncology. 2011;81:192-8.

21. Rego RL, Foster NR, Smyrk TC, Le M, O'Connell MJ, Sargent DJ, et al. Prognostic effect of activated EGFR expression in human colon carcinomas: comparison with EGFR status. Br J Cancer. 2010;102:165-72.

22. Hong L, Han $Y$, Yang J, Zhang H, Jin $Y$, Brain L, et al. Prognostic value of epidermal growth factor receptor in patients with gastric cancer: a metaanalysis. Gene. 2013;529:69-72.

23. Valsecchi ME, McDonald M, Brody JR, Hyslop T, Freydin B, Yeo CJ, et al. Epidermal growth factor receptor and insulinlike growth factor 1 receptor expression predict poor survival in pancreatic ductal adenocarcinoma. Cancer. 2012;118:3484-93.

24. Perini MV, Montagnini AL, Coudry R, Patzina R, Penteado S, Abdo EE, et al. Prognostic significance of epidermal growth factor receptor overexpression in pancreas cancer and nodal metastasis. ANZ J Surg. 2015;85:174-8.

25. Luo G, Long J, Qiu L, Liu C, Xu J, Yu X, et al. Role of epidermal growth factor receptor expression on patient survival in pancreatic cancer: a metaanalysis. Pancreatology. 2011;11:595-600.

26. Smith RA, Tang J, Tudur-Smith C, Neoptolemos JP, Ghaneh P. Meta-analysis of immunohistochemical prognostic markers in resected pancreatic cancer. Br J Cancer. 2011:104:1440-51.

27. Wiseman SM, Makretsov N, Nielsen TO, Gilks B, Yorida E, Cheang M, et al. Coexpression of the type 1 growth factor receptor family members HER-1, HER-2, and HER-3 has a synergistic negative prognostic effect on breast carcinoma survival. Cancer. 2005:103:1770-7.

28. te Velde EA, Franke AC, van Hillegersberg R, Elshof SM, de Weger RW, Borel

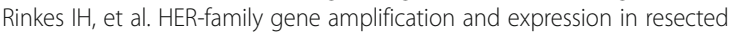
pancreatic cancer. Eur J Surg Oncol. 2009;35:1098-104.

29. Aumayr K, Soleiman A, Sahora K, Schindl M, Werba G, Schoppmann SF, et al. HER2 gene amplification and protein expression in pancreatic ductal adenocarcinomas. Appl Immunohistochem Mol Morphol. 2014;22:146-52.

30. Komoto M, Nakata B, Amano R, Yamada N, Yashiro M, Ohira M, et al. HER2 overexpression correlates with survival after curative resection of pancreatic cancer. Cancer Sci. 2009:100:1243-7.

31. Thomas G, Chardès T, Gaborit N, Mollevi C, Leconet W, Robert B, et al. HER3 as biomarker and therapeutic target in pancreatic cancer: new insights in pertuzumab therapy in preclinical models. Oncotarget. 2014;5:7138-48.

32. Ocana A, Vera-Badillo F, Seruga B, Templeton A, Pandiella A, Amir E, et al. HER3 overexpression and survival in solid tumors: a meta-analysis. J Natl Cancer Inst. 2013;105:266-73.

33 Graber HU, Friess H, Kaufmann B, Willi D, Zimmermann A, Korc M, et al. ErbB-4 mRNA expression is decreased in non-metastatic pancreatic cancer. Int J Cancer. 1999:84:24-7.

34 Thybusch-Bernhardt A, Beckmann S, Juhl H. Comparative analysis of the EGF-receptor family in pancreatic cancer: expression of HER-4 correlates with a favourable tumor stage. Int J Surg Investig. 2001;2:393-400.

\section{Submit your next manuscript to BioMed Central and we will help you at every step:}

- We accept pre-submission inquiries

- Our selector tool helps you to find the most relevant journal

- We provide round the clock customer support

- Convenient online submission

- Thorough peer review

- Inclusion in PubMed and all major indexing services

- Maximum visibility for your research

Submit your manuscript at www.biomedcentral.com/submit
) Biomed Central 